\title{
The role of autogrooming in the differential susceptibility to tracheal mite (Acarapis woodi) infestation of honeybees (Apis mellifera) held at both normal and reduced temperatures during pupation*
}

\author{
John B. MCMULLAN, Mark J.F. BROWN \\ School of Natural Sciences, Department of Zoology, University of Dublin Trinity College, Dublin 2, Ireland
}

Received 18 August 2005 - revised 7 November 2005 - accepted 21 November 2005

\begin{abstract}
In previous work we demonstrated that honeybees held at a reduced temperature $\left(30^{\circ} \mathrm{C}\right)$ during pupation, exhibited a significant increase in their susceptibility to tracheal mite infestation. Here, we investigated the potential role of grooming in producing this effect. We compared the susceptibility of bees with and without the mesotarsi of their thorax grooming legs, raised at the two pupation temperatures. (1) Bees held at normal pupation temperature. A colony with high susceptibility (low resistance) had little grooming ability while in a low susceptibility colony, grooming ability made a significant contribution to its reduced susceptibility. (2) Bees held at reduced pupation temperature. In a high susceptibility colony there was evidence that reduced grooming ability made little contribution to the increased infestation. This was in contrast to a low susceptibility colony raised at a reduced temperature where reduced grooming was implicated in the increased susceptibility.
\end{abstract}

Apis mellifera / Acarapis woodi / tracheal mite / grooming behaviour / infestation

\section{INTRODUCTION}

The tracheal mite Acarapis woodi (Rennie) (Acari: Tarsonemidae) is an obligate parasite of the honeybee, Apis mellifera L. (Hymenoptera: Apidae). It was first identified in 1919 in Scotland (Rennie, 1921) and was found as a result of investigations undertaken to discover the cause of an epidemic in honeybee colonies that first occurred in 1904 on the Isle of Wight and later spread to the rest of Britain, Ireland and mainland Europe (Adam, 1968). Some considered that the $A$. woodi mite was not a serious threat to bees. However, the tracheal mite was first recorded in North America in 1984 (Otis and ScottDupree, 1992) and soon became associated with mortality of bee colonies.

Corresponding author: J.B. McMullan, jmcmullan@eircom.net

* Manuscript editor: Stefan Fuchs
It is widely accepted that there is a significant increase in mortality in winter where $>$ $30 \%$ of bees in a hive are infested with tracheal mites (Bailey, 1961). While other pathogens can be involved there is little evidence of them having had a prominent role (Adam, 1968; Collison, 2001). This has been the recent experience of mortality in tracheal mite infested colonies in Ireland (J. McM. personal observation). Studies have shown that winter mortality rates in colonies with tracheal mites are generally higher in cold climates (Eischen, 1987; Otis and Scott-Dupree, 1992).

In a previous study to identify possible reasons for this mortality, bees pupated at a low brood temperature $\left(30^{\circ} \mathrm{C}\right)$ were shown to be twice as susceptible to infestation as those pupated at a more typical temperature of $34{ }^{\circ} \mathrm{C}$ (McMullan and Brown, 2005). We suggest that this is a link in a chain of events leading to the mortality of temperature stressed colonies 
in the late winter / early spring period. Honeybees in a colony with a moderate tracheal mite infestation have a reduced ability to use their wing muscles to generate thoracic heat (Komeili and Ambrose, 1991). Hence a reduced brood temperature will increase the rate of infestation of callow bees, which in turn will relate to a reduced area of brood in the colony (Otis and Scott-Dupree, 1992). This reduced addition of new bees to replace the old winter bees will tend to further reduce the brood temperature, increase susceptibility and the viability of the colony will decline.

The reason for the increased susceptibility of bees reared at a lower temperature is not known. One possible reason is that the reduced brood temperature impaired the grooming ability of the callow bees. Sammataro and Needham (1996) showed that mated female mites leave the tracheae of their host bees and migrate to new, young host bees via the plumose hair. Autogrooming was demonstrated by Danka and Villa (1998) as an important defence mechanism against infestation by the tracheal mites. Since honeybees can use their mesothoracic (middle) legs to groom the thorax, restricting the grooming ability of these legs will affect the success rate of female mites entering the tracheae. In fact removing the mesothoracic legs had the effect of equalising, to a large extent, the mite susceptibility of bees from high and low resistance colonies. Danka and Villa (1998) also showed that removing only the lower segments of the legs (mesotarsi) had a similar influence as the complete removal of the mesothoracic legs.

An experiment was therefore designed to test changes in grooming behaviour and to answer the following questions: (i) Does grooming ability explain resistance to tracheal mites in normally pupated honeybee colonies? and (ii) Is the increased tracheal mite susceptibility of honeybees pupated at a reduced brood temperature $\left(30^{\circ} \mathrm{C}\right)$ caused by a reduced grooming ability?

\section{MATERIALS AND METHODS}

\subsection{Laboratory bioassay}

The experiment was undertaken in the April and May period 2004 using a laboratory bioassay and testing bees from colonies in North County Dublin, Ireland. This is a similar approach to that used in the experiment that demonstrated a pupationtemperature effect in susceptibility (McMullan and Brown, 2005). Previous experiments on honeybee susceptibility have shown a good correlation between the results from such short-term bioassays and field colonies (Page and Gary, 1990; Danka and Villa, 1996; Nasr et al., 2001).

\subsection{Host bees}

The host bees came from an infested colony where the mite prevalence had been increased in the previous month by removing emerging brood frames. (This has the effect of increasing the mite prevalence by concentrating them in the callow bees that emerge from the remaining frames). A cordless car vacuum cleaner (Black and Decker, Dustmaster V9650) was modified, based on the design of Gary and Lorenzen (1987), and this was used to gather the host bees directly into the inoculation cages. On the 7th May 2004 each inoculation cage was filled in turn with an estimated 350 infested worker bees collected from the landing board of the colony. A separate sample of sixty bees, thirty before and thirty after filling the inoculation cage, was also taken from the landing board of the host colony, placed in numbered boxes and stored at $-30{ }^{\circ} \mathrm{C}$. These 60 bees were later dissected to give a measure of the initial host-bee infestation level in the cage. This initial infestation level should give a reasonable measure of the relevant inoculation pressure in the cage as most of the mite transfer takes place in the first 1/2 days (Morgenthaler, 1931; Bailey, 1958; Lee, 1963; Giordani, 1977; Gary et al., 1989). The procedure was repeated for the other inoculation cage.

\subsection{Target bees}

The target bees were obtained from two colonies in separate apiaries in North County Dublin, Ireland. One apiary was located in an urban coastal area, and the other in a rural area five miles from the coast. Tracheal mites had never been detected in over thirty-five years in the first apiary, while the bees in the second apiary were infested on an ongoing basis. Varroa mites were only present in the second apiary and were at a low level after treatment with Bayvarol ${ }^{\mathrm{TM}}$ in the previous autumn. A frame 
of brood with the adhering bees brushed off was taken from each of the colonies on 28th April 2004 and each inserted into a separate perforated stainless steel frame cage. These cages were put into insulated nucleus boxes, transported to the laboratory and transferred to a dark incubator at $30{ }^{\circ} \mathrm{C}$ and a relative humidity of $54 \%( \pm 7)$ within half an hour of leaving the hive. For the following 9 days callow bees were removed morning and evening from each of the frame cages. These bees were not included in the experiment. On 7th May (9 days later) a second frame of brood, that was adjacent in the hive to the frame already removed, was taken from each of the target colonies and incubated in the dark at normal hive temperature and relative humidity (until sufficient callow bees had been collected). The brood temperature of the two target colonies had been monitored while the frames were in the hive to ensure that the brood was being pupated at normal hive temperature. During the period, temperature readings [median (range)] of $34.6{ }^{\circ} \mathrm{C}( \pm 0.5)$ and $34.4{ }^{\circ} \mathrm{C}( \pm 0.5)$ were recorded for colonies 1 and 2 respectively. Sample readings of the relative humidity $(\mathrm{RH})$ in the hive were in the range $56 \%$ $( \pm 10)$. Hence the control bees were pupating for 9 days at the normal hive temperature and $\mathrm{RH}$ and the treatment bees at $30{ }^{\circ} \mathrm{C}$ and normal $\mathrm{RH}$.

On the same day (7th May) callow bees emerging from the four frames (two from each colony) were collected in separate polystyrene cups that had a smear of petroleum jelly along the top to prevent the callow bees from climbing out. Taking each colony in turn, bees were chosen randomly from the polystyrene cups and (using surgical gloves to handle them) a 1-2 mm spot of Testor's ${ }^{\mathrm{TM}}$ gloss enamel paint was applied to the V-VI tergites on the abdomen of the callow bees; i.e. four different colours were used to mark the four target-bee samples. One sample was taken from each of the two cups with bees pupated at $34{ }^{\circ} \mathrm{C}$ and $30{ }^{\circ} \mathrm{C}$ and one sample was also taken from each of these cups and these bees had the mesotarsus removed (by microdissection spring scissors) from both of their mesothoracic legs. All bees were handled in a similar manner. The four samples of bees from each colony were introduced by funnel into each of the two inoculation cages giving a total of 120 marked target bees in each cage.

\subsection{Inoculation process}

The inoculation cages were maintained in a dark incubator at $32{ }^{\circ} \mathrm{C}$ and $50 \% \mathrm{RH}$. The bees were pro- vided ad libitum with sugar syrup (50\%) and water via gravity feeding vials at the top of the cages. A supply of freshly gathered pollen was delivered through the vial-feed openings on top thus enabling access even when dead bees gathered on the floor. The experiment was concluded after 7 days, based on the evidence that the first adult mites to mature are the males after 8 days (Pettis and Wilson, 1989). Hence after 7 days the only adult mites present were the founding females. The dead bees were removed from the bottom of the cage, segregated and counted. The live bees were killed with $\mathrm{CO} 2$ gas, and taking each cage in turn were segregated into host bees and the four categories of target bees, and counted. They were then placed in numbered boxes and stored at $-30{ }^{\circ} \mathrm{C}$ to await dissection.

\subsection{Dissection technique}

The bees were dissected using a modification to the classic technique of removing the head and thoracic collar as described by Shimanuki and Knox (2000). The prothoracic tracheae were removed and placed on double-sided tape attached to a glass slide. In order to protect the trachea at the spiracle end (to avoid bursting eggs or damaging larvae clustered behind the operculum), part of the adjacent cuticle (including the spiracle) was cut with scissors and left attached to the trachea. In all cases an effort was made to retain the maximum length of trachea beyond the first branch. Under a stereomicroscope at 60-100X magnification, each trachea was opened with a dissecting needle and the number of adult mites, larvae and eggs were counted and recorded.

\subsection{Statistical analyses}

The female mite abundance data (total number of mites per bee in a sample) were skewed and had variances that were generally in proportion to the sample means. Accordingly, the mite count data were transformed to $\log _{10}(y+1)$ (Sokal and Rohlf, 1995). Mite abundance data (control vs. test) were analysed as a 1-way ANOVA for the single-colony data, or as a 2-way ANOVA for the all-colonies data with treatment and colony as fixed factors. 


\section{RESULTS}

\subsection{Host bee - recovery, mortality and mite prevalence}

The initial number of host bees was 382 and 387 for the inoculation cages 1 and 2 with the proportion of live bees at the end of the experiment at $69 \%$ and $78 \%$ respectively. The samples of 60 bees that were taken to give a measure of the initial inoculation pressure had similar mite prevalence levels of 16/60, and 13/60 for cages 1 and 2 respectively (Tab. I).

\subsection{Target bee - mite abundance and fecundity}

The infestation data for all colonies and treatments are given in Table I. In instances where mite offspring were present in the trachea and no adult mite found, it was assumed that the foundress female mite had migrated further into the trachea (Gary et al., 1989). In these cases one female mite was assigned to the mite total to give an adjusted female mite abundance.

The overall fecundity data (offspring/ female mite) were similar for all treatments with means $( \pm$ s.e.) of $5.53( \pm 0.33), 5.14$ $( \pm 0.24), 5.00( \pm 0.0 .29)$ and $4.93( \pm 0.36)$ for treatments $34{ }^{\circ} \mathrm{C}, 34^{\circ} \mathrm{C}$ (restricted grooming), $30{ }^{\circ} \mathrm{C}$ and $30{ }^{\circ} \mathrm{C}$ (restricted grooming), respectively $\left(F_{[3,85]}=0.241, P=0.868\right)$. The fecundity data were also similar for the colonies with means $( \pm$ s.e.) of $4.88( \pm 0.25)$ and $5.32( \pm 0.18)$ for colonies 1 and 2 respectively $\left(F_{[1,85]}=1.917, P=0.17\right)$. Accordingly, the adjusted female mite abundance is used in the analysis and this is given for all colonies in Figure 1.

\subsection{Unrestricted grooming $\left(34^{\circ} \mathrm{C}\right.$ and $30{ }^{\circ} \mathrm{C}$ )}

There was a $50 \%$ increase in the overall (both colonies) female mite abundance (mean \pm s.e.) from $0.41 \pm 0.08$ mites $/$ bee at $34{ }^{\circ} \mathrm{C}$ to $0.62 \pm 0.10 \mathrm{mites} / \mathrm{bee}$ at $30{ }^{\circ} \mathrm{C}\left(F_{[1,109]}=\right.$ 3.036, $P<0.084)$. The marginal statistical significance of this increase in abundance

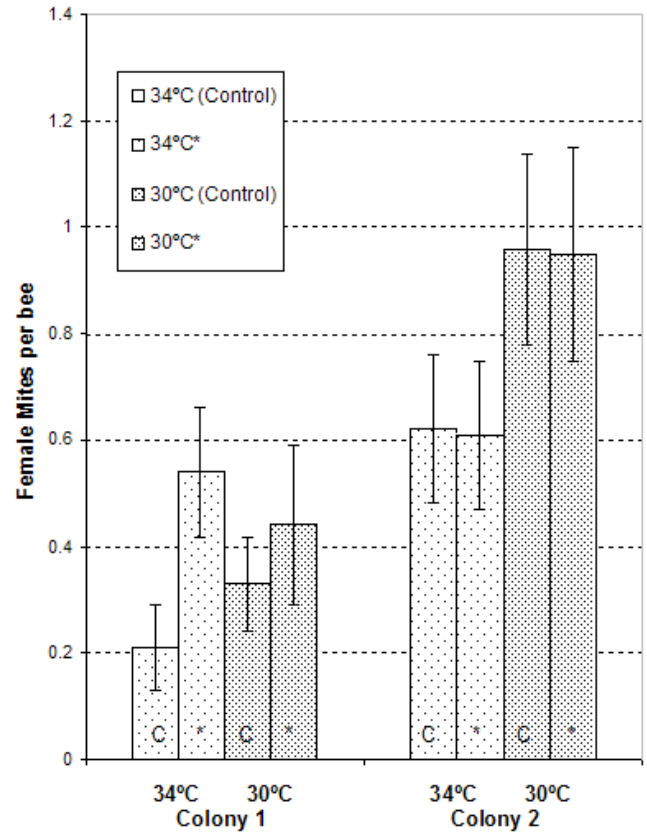

Figure 1. Female mite abundance for the target bees for all colonies and treatments. The figure illustrates the effect of the treatments on the female mite abundance (mean mites per bee \pm s.e.). The control bee data bars are denoted by ' $\mathrm{C}$ ' and the treated bee (restricted grooming) data by ' $*$ '.

is a sample-size effect, as when data from a third colony inoculated in parallel with the two colonies used in the experiment are included in the analysis the increase becomes statistically significant $\left(F_{[1,159]}=5.613, P=0.019\right)$. Including data from this third colony, the resulting overall abundance (mean \pm s.e.) increased by two-thirds from $0.41 \pm 0.07 \mathrm{mites} / \mathrm{bee}$ at $34{ }^{\circ} \mathrm{C}$ to $0.67 \pm 0.09 \mathrm{mites} /$ bee at $30{ }^{\circ} \mathrm{C}$. In the case of the two colonies, there was a significant colony effect with female mite abundance (mean \pm s.e.) increasing from $0.27 \pm 0.06$ mites/bee for colony 1 to $0.78 \pm 0.11$ mites/bee for colony $2\left(F_{[1,109]}=16.155, P<0.001\right)$. There was no significant interaction between treatment and colony $\left(F_{[1,109]}=0.287, P<\right.$ $0.593)$.

A measure of the relative susceptibility (or resistance) of a colony to infestation by the tracheal mite is its infestation performance at normal pupation temperature $\left(34{ }^{\circ} \mathrm{C}\right)$ compared to 
Table I. Summary of mite infestation levels for host and target bees in the two inoculation cages and colonies for all treatments.

\begin{tabular}{|c|c|c|c|c|c|c|}
\hline \multirow{2}{*}{$\begin{array}{l}\text { Bee } \\
\text { Colony }\end{array}$} & \multirow{2}{*}{$\begin{array}{c}\text { Control/ } \\
\text { Treatment }\end{array}$} & \multirow{2}{*}{$\begin{array}{c}\text { No. of bees } \\
\text { Total (infested) }\end{array}$} & \multicolumn{4}{|c|}{ Mite stages } \\
\hline & & & Adults (adj. ${ }^{1}$ ) & Larvae & Eggs & Total \\
\hline \multicolumn{7}{|l|}{ Cage 1} \\
\hline Host: & Before & $60(16)$ & 56 & 160 & 74 & 290 \\
\hline \multicolumn{7}{|l|}{ Target: } \\
\hline \multirow[t]{4}{*}{ Colony 1} & $34{ }^{\circ} \mathrm{C}$ & $29(6)$ & $6(6)$ & 11 & 17 & 34 \\
\hline & $34^{\circ} \mathrm{C}^{*}$ & $28(13)$ & $14(15)$ & 31 & 46 & 91 \\
\hline & $30^{\circ} \mathrm{C}$ & $30(10)$ & $8(10)$ & 20 & 26 & 54 \\
\hline & $30^{\circ} \mathrm{C}^{*}$ & $25(8)$ & $10(11)$ & 24 & 30 & 64 \\
\hline \multicolumn{7}{|l|}{ Cage 2} \\
\hline Host: & Before & $60(13)$ & 25 & 96 & 54 & 175 \\
\hline \multicolumn{7}{|l|}{ Target: } \\
\hline \multirow[t]{4}{*}{ Colony 2} & $34{ }^{\circ} \mathrm{C}$ & $29(15)$ & $14(18)$ & 62 & 42 & 118 \\
\hline & $34^{\circ} \mathrm{C}^{*}$ & $28(14)$ & $12(17)$ & 48 & 37 & 97 \\
\hline & $30^{\circ} \mathrm{C}$ & $25(15)$ & $17(24)$ & 65 & 58 & 140 \\
\hline & $30^{\circ} \mathrm{C}^{*}$ & $20(12)$ & $14(19)$ & 46 & 46 & 106 \\
\hline
\end{tabular}

* Restricted grooming.

${ }^{1}$ Adjusted by adding to the actual female mites present in the target bees an allocation of one female mite for each occasion that offspring was present without a corresponding female mite.

Table II. Summary of significance tests on adjusted female mite abundance data from the two colonies and for all treatments. A log transformation was used on the abundance data which were then analysed using a 1-way ANOVA.

\begin{tabular}{lccccc}
\hline Treatment & $\begin{array}{c}\text { Mite abundance untransformed data } \\
\text { per bee }(\text { mean } \pm \text { s.e. })\end{array}$ & \multicolumn{4}{c}{ Significance tests on transformed data } \\
\cline { 3 - 6 } & & Control/Treatment & d.f. & $F$-value & $P$ \\
\hline Colony 1 & $0.21 \pm 0.08$ & Control & - & - & - \\
$34^{\circ} \mathrm{C}$ & $0.54 \pm 0.09$ & Treatment & 1,55 & 5.152 & 0.027 \\
$34^{\circ} \mathrm{C}^{*}$ & $0.33 \pm 0.09$ & Control & - & - & - \\
$30^{\circ} \mathrm{C}$ & $0.44 \pm 0.15$ & Treatment & 1,53 & 0.117 & 0.743 \\
$30^{\circ} \mathrm{C}^{*}$ & & & & & \\
& & & & & - \\
Colony 2 & $0.62 \pm 0.14$ & Control & - & - & - \\
$34^{\circ} \mathrm{C}$ & $0.61 \pm 0.14$ & Treatment & 1,55 & 0.009 & 0.924 \\
$34^{\circ} \mathrm{C}^{*}$ & $0.96 \pm 0.18$ & Control & - & - & - \\
$30^{\circ} \mathrm{C}$ & $0.95 \pm 0.20$ & Treatment & 1,43 & 0.001 & 0.978 \\
$30^{\circ} \mathrm{C}^{*}$ & & & & & \\
\hline
\end{tabular}

* Restricted grooming.

another colony when exposed to a similar inoculation pressure. There was a significant difference between the mean female mite abundance of target bees from colony 1 and colony 2 at $34{ }^{\circ} \mathrm{C}\left(F_{[1,56]}=7.316, P=0.009\right)$ when subjected to host bees from the same mite infested colony. Table II shows that the abundance varied widely from a mean $( \pm$ s.e. $)$ of
$0.21 \pm 0.08 \mathrm{mites} / \mathrm{bee}$ in colony 1 ('low susceptibility' colony) to $0.62 \pm 0.14$ mites/bee in colony 2 ('high susceptibility' colony). The designations of low and high susceptibilities are also consistent with the colony disease history as tracheal mites had never been detected in colony 1 while tracheal mite infestation was ongoing in colony 2 . 


\subsection{Evaluating the grooming capability of bees raised at $34{ }^{\circ} \mathrm{C}$}

There is evidence that the grooming ability of normally pupated bees is colony dependent (Tab. II, Fig. 1). In the case of colony 1, a low susceptibility colony, there was a significant increase in susceptibility when grooming was restricted $\left(F_{[1,55]}=5.152, P=0.027\right)$. The female mite abundance (mean \pm s.e.) increased from $0.21 \pm 0.08$ to $0.54 \pm 0.09$ mites per bee. This was in contrast to colony 2 , a high susceptibility colony, where the response was minimal $\left(F_{[1,55]}=0.009, P=0.924\right)$ and the mean varied from $0.62 \pm 0.14$ to $0.61 \pm 0.14$ mites per bee. The mite abundance in the low susceptibility colony (colony 1) when grooming was restricted was just $13 \%$ lower than that in the high susceptibility colony (colony 2) when grooming was unrestricted i.e. $0.54 \mathrm{fe}$ male mites/bee vs. 0.62 female mites/bee.

\subsection{Evaluating the contribution that changes in grooming make to the increased susceptibility of bees raised at $30{ }^{\circ} \mathrm{C}$}

It is assumed that the grooming restriction applied to the bees has the effect of removing all their grooming capability. Hence the change in susceptibility (due to restricted grooming) in bees pupated at $30^{\circ} \mathrm{C}$ when compared to the change in bees pupated at $34{ }^{\circ} \mathrm{C}$ is a measure of the contribution that grooming makes to the increased susceptibility of unconstrained bees raised at $30{ }^{\circ} \mathrm{C}$. The test bees pupated at $30{ }^{\circ} \mathrm{C}$ had only a small response to restricted grooming, with changes in susceptibility of 0.11 and 0.01 mites per bee respectively for colonies 1 , and 2 , none of which were statistically significant (Tab. II, Fig. 1). The two samples of test bees pupated at $34{ }^{\circ} \mathrm{C}$ had a colony dependent response to restricted grooming as described in Section 3.4 above. The changes in susceptibility were 0.33 and 0.02 mites per bee respectively for colonies 1 and 2, with the former being a statistically significant difference (Tab. II). There are therefore indications that in the high susceptibility colony (colony 2 ) reduced grooming makes very little contribution to the increased susceptibility of bees held at $30{ }^{\circ} \mathrm{C}$ during pupation because these bees were initially poor groomers. In contrast, in the low susceptibility colony (colony 1) there are indications that reduced grooming may have made a contribution to the increased susceptibility of bees pupated at $30{ }^{\circ} \mathrm{C}$.

\section{DISCUSSION}

Bees pupated at the lower brood temperature of $30{ }^{\circ} \mathrm{C}$ (with unrestricted grooming) had a higher susceptibility to tracheal mite infestation than those raised at the more typical brood temperature of $34^{\circ} \mathrm{C}$. This concurs with the results of our previous work (McMullan and Brown, 2005) and reaffirms that a low pupation temperature considerably increases the likelihood of honeybees being infested. Mite fecundity was also shown to be similar for all colonies and treatments. This is in line with the findings of Danka and Villa (1996) and McMullan and Brown (2005) that the mite reproduction in the honeybee trachea is similar and that differential mite abundance is determined by the success rate of the female mites migrating to the new hosts.

We demonstrated that in the case of bees pupated at a normal temperature, grooming is an important element in the reduced infestation in a colony with low mite susceptibility (e.g. colony 1 ), while in a colony with high susceptibility (e.g. colony 2 ) the ability to groom had no influence on susceptibility. Also, the low susceptibility colony with restricted grooming (colony $1,34{ }^{\circ} \mathrm{C}^{*}$ ) had a susceptibility close to that of the high susceptibility colony (colony $2,34{ }^{\circ} \mathrm{C}$ ). Hence there is evidence that the differential susceptibility of colonies to tracheal mite infestation in normally pupated bees is explained to a large extent by the autogrooming capability of the colonies. This is consistent with the findings of Danka and Villa (1998).

The experiment explored whether grooming could explain the increased susceptibility to tracheal mite infestation of bees pupated at a low temperature $\left(30^{\circ} \mathrm{C}\right)$. In the case of a high susceptibility colony (colony 2 ) there was no 
evidence that grooming made a contribution to the increase in susceptibility caused by the low pupation temperature. If there was no interaction between treatment (grooming restriction) and colony (genetically based susceptibility) then we would expect the data from colony 1 to show a similar pattern, with the bees in the restricted grooming samples $\left(34{ }^{\circ} \mathrm{C}^{*}\right.$ and $30^{\circ} \mathrm{C}^{*}$ ) exhibiting similar mite abundances to their respective control samples $\left(34{ }^{\circ} \mathrm{C}\right.$ and $30{ }^{\circ} \mathrm{C}$ ). However, this was not the case, as the restricted grooming bees in colony 1 had a considerably greater change in mite abundance. The change (increase) in abundance was much greater with the $34{ }^{\circ} \mathrm{C}$ treated bees $\left(34{ }^{\circ} \mathrm{C}\right.$ to $\left.34{ }^{\circ} \mathrm{C}^{*}\right)$ than with the $30^{\circ} \mathrm{C}$ treated bees $\left(30{ }^{\circ} \mathrm{C}\right.$ to $\left.30{ }^{\circ} \mathrm{C}^{*}\right)$ indicating that reduction in grooming ability made a contribution to the increased susceptibility of $30{ }^{\circ} \mathrm{C}$ pupated bees. In high susceptibility colonies raised at a reduced pupation temperature it is therefore indicated that mechanisms other than grooming are responsible for the increased susceptibility. Recent research by Tautz et al. (2003) showed that bees raised at a reduced brood temperature had a considerably lower foragedance activity and had a reduced cognitive ability. Hence physiological traits (other than grooming) or the influence of cuticular hydrocarbons may be accounting for the increased mite susceptibility. Further work is required to isolate these mechanisms.

This experiment involved colonies that had a wide spread in their measured susceptibility to tracheal mites. Since the results of this experiment indicated that the characteristics of susceptibility in both normally and reduced-temperature pupated bees are colony dependent, further work is required to analyse such colony-level variation. Future test colonies should be replicated on the basis of high/low susceptibility to mite infestation.

\section{ACKNOWLEDGEMENTS}

The authors would like to thank the members of Fingal North Dublin Beekeepers' Association and John \& Dorothy Stapleton for access to honeybee colonies, and Martyn Linnie, Peter Stafford and Alison Boyce for help in the laboratory. Helpful com- ments from S. Fuchs and two anonymous reviewers improved the clarity of the manuscript.

Résumé - Rôle de l'auto-toilettage dans les différentes sensibilités à l'infestation par Acarapis woodi des abeilles domestiques (Apis mellifera) maintenues à des températures normales et réduites durant la nymphose. Au cours des cent dernières années l'acarien des trachées, Acarapis woodi (Acari, Tarsonemidae), a été associé à l'infestation et la mortalité de colonies d'abeilles (Apis mellifera L.). Il est d'abord apparu en Grande Bretagne et en Irlande, puis s'est répandu dans le monde entier. L'acarien se trouve principalement dans les trachées du prothorax et se nourrit de l'hémolymphe de l'abeille. Nos travaux précédents ont montré que le maintien des abeilles à une température réduite $\left(30^{\circ} \mathrm{C}\right)$ durant la nymphose augmentait significativement la sensibilité (McMullan and Brown, 2005).

Nous avons cherché à déterminer la contribution de l'auto-toilettage à la sensibilité d'abeilles élevées à la température normale (TN) de nymphose ou à une température réduite (TR). Des abeilles élevées à la TN ou à la TR ont été comparées à des abeilles élevées aux mêmes températures mais dont les mésotarses de la patte toilettant le thorax avaient été ôtés. Il a été montré que la suppression des mésotarses empêchait le toilettage du thorax (Danka et Villa, 1998). Les résultats montrent que la fécondité des acariens dans les quatre échantillons de chaque colonie était identique et que l'abondance des acariens était déterminée par le taux de succès de migration des acariens femelles.

La capacité des abeilles à s'auto-toiletter avait un effet significatif sur la sensibilité des abeilles d'une colonie faiblement sensible, élevées à la $\mathrm{TN}$ de nymphose (Tab. II). Les abeilles d'une colonie fortement sensible, élevées à la $\mathrm{TN}$, avaient une très faible capacité au toilettage. Dans le cas des abeilles d'une colonie fortement sensible, élevées à la TR, la réduction de l'auto-toilettage a très peu contribué à l'augmentation de la sensibilité. Par contre, pour les abeilles d'une colonie faiblement sensible élevées à la TR, la réduction de l'auto-toilettage a contribué à augmenter la sensibilité.

Apis mellifera / Acarapis woodi / comportement de toilettage / infestation

Zusammenfassung - Die Bedeutung des sich Putzens für unterschiedliche Anfälligkeit bei Infektionen mit Tracheenmilben (Acarapis woodi) bei Honigbienen (Apis mellifera) nach Haltung bei normaler und niedriger Temperatur während der Verpuppung. Die Tracheenmilbe (Acarapis woodi (Rennie)) wurde im letzten Jahrhundert mit dem Befall und der Sterblichkeit von Völkern der Honigbienen (Apis mellifera L.) in Verbindung 
gebracht. Sie trat ursprünglich in Britannien und Irland auf und verbreitete sich später bei Honigbienen der ganzen Welt. Die Milbe hält sich hauptsächlich in Tracheen des Prothorax auf und ernährt sich von Hämolymphe. In früheren Arbeiten zeigten wir, dass Bienen während der Verpuppung bei reduzierter Temperatur $\left(30^{\circ} \mathrm{C}\right)$ eine signifikant erhöhte Anfälligkeit zeigten (McMullan and Brown, 2005). Im folgenden wurde die Bedeutung des sich selbst Putzens auf die Anfälligkeit bei Bienen untersucht, die bei normalen bzw. reduzierten Temperaturen aufgezogen wurden. Die Völker hatten Brut bei normaler und reduzierter Temperatur aufgezogen, und diese wurden mit Bienen beider Verpuppungstemperaturen verglichen, deren Mesotarsen von den Beinen, die zum Putzen des Thorax benutzt werden, entfernt wurde. Die Entfernung der Mesotarsen bewirkt einen deutlichen Verlust der Fähigkeit sich zu putzen (Danka and Villa, 1998). Die Ergebnisse zeigten, dass die Fruchtbarkeit der Milben in den 4 Proben aus jedem Volk ähnlich war, und dass das Vorkommen der Milben durch die Erfolgsrate von wandernden Milbenweibchen bestimmt wurde. Es wurde nachgewiesen, dass die Fähigkeiten der Bienen sich zu putzen einen signifikanten Einfluss hat auf die Anfälligkeit der Bienen eines gering anfälligen Volkes bei Aufzucht unter normalen Verpuppungstemperaturen (Tab. II). Es gab auch Beweise dafür, dass Bienen eines anfälligen Volkes, das bei normaler Verpuppungstemperatur aufgezogen wurde, nur geringe Fähigkeiten des sich Putzens hatten. Bei Bienen eines stark anfälligen Volkes, die sich bei geringen Temperaturen verpuppten, konnte gezeigt werden, dass das sich Putzen nur einen sehr kleinen Beitrag zur erhöhten Anfälligkeit stellte. Es gab jedoch Hinweise darauf, dass im Fall von Bienen eines gering anfälligen Volkes, die sich bei geringen Temperaturen verpuppten, eine Reduzierung des sich Putzens zur Erhöhung der Anfälligkeit beigetragen hat.

\section{Apis mellifera / Acarapis woodi / Tracheenmilbe / Putzverhalten / Verseuchung}

\section{REFERENCES}

Adam Brother (1968) "Isle of Wight" or acarine disease: Its historical and practical aspects, Bee World 49, 6-18.

Bailey L. (1958) The epidemiology of the infestation of honeybee, Apis mellifera L., by the mite Acarapis woodi Rennie and the mortality of bees, Parasitology 48, 493-506.

Bailey L. (1961) The natural incidence of Acarpis woodi (Rennie) and the winter mortality of honeybee colonies, Bee World 42, 96-100.

Collison C.H. (2001) The pathological effects of the tracheal mite on its host, in: Webster T.C.,
Delaplane K.S. (Ed.), Mites of the honeybee, Dadant and Sons, Hamilton, Illinois, pp. 57-71.

Danka R.G., Villa J.D. (1996) Influence of resistant honey bee hosts on the life history of the parasite Acarapis woodi, Exp. Appl. Acarol. 20, 313-322.

Danka R.G., Villa J.D. (1998) Evidence of autogrooming as a mechanism of honeybee resistance to tracheal mite infestation, J. Apic. Res. 37, 39-46.

Eischen F.A. (1987) Overwintering performance of honey bee colonies heavily infested with Acarapis woodi (Rennie), Apidologie 18, 293-304.

Gary N.E., Lorenzen K. (1987) Vacuum device for collecting and dispensing honeybees (Hymenoptera: Apidae) and other insects into small cages, Ann. Entomol. Soc. Am. 80, 664-666.

Gary N.E., Page R.E., Lorenzen K. (1989) Effect of age of worker honeybees (Apis mellifera) on tracheal mites (Acarapis woodi) infestation, Exp. Appl. Acarol. 7, 153-160.

Giordini G. (1977) Facts about acarine mites, in: XXVI Proc. Int. Congr. Apic. Adelaide, Bucharest, Apimondia, pp. 459-467.

Komeili A.B., Ambrose J.T. (1991) Electron microscope studies of the tracheae and flight muscles of noninfested, Acarapis woodi infested and crawling honey bees Apis mellifera, Am. Bee J. 131, 253-257.

Lee D.C. (1963) The susceptibility of honey bees of different ages to infestation by Acarapis woodi (Rennie), J. Insect Pathol. 5, 11-15.

McMullan J.B., Brown M.J.F. (2005) Brood pupation temperature affects the susceptibility of honeybees (Apis mellifera L.) to infestation by tracheal mites (Acarapis woodi), Apidologie 36, 97-105.

Morgenthaler O. (1931) An acarine disease experimental apiary in the Bernese Lake-District and some results obtained there, Bee World 12, 8-10.

Nasr M.E., Otis G.W., Scott-Dupree C.D. (2001) Resistance to Acarapis woodi by honey bees (Hymenoptera: Apidae): Divergent selection and evaluation of selection process, J. Econ. Entomol. 94, 332-338.

Otis G.W., Scott-Dupree C.D. (1992) Effects of Acarapis woodi on overwintered colonies of honey bees (Hymenoptera: Apidae) in New York, J. Econ. Entomol. 85, 40-46.

Page R.E., Gary N.E. (1990) Genotypic variation in susceptibility of honeybees (Apis mellifera) to infestation by tracheal mites (Acarapis woodi), Exp. Appl. Acarol. 8, 275-283.

Pettis J.S., Wilson W.T. (1989) Reproduction of Acarapis woodi as related to seasonal host longevity, Am. Bee J. 129, 820.

Rennie J. (1921) Isle of Wight disease in hive bees - acarine disease: the organism associated with the disease - Tarsonemus woodi, Trans. R. Soc. Edinburgh 52, 768-779. 
Sokal R.R., Rohlf F.J. (1995) Biometry, W. H. Freeman and Company, New York, pp. 413-415.

Sammataro D., Needham G.R. (1996) Host-seeking behaviour of tracheal mites (Acari: Tarsonemidae) on honey bees (Hymenoptera: Apidae), Exp. Appl. Acarol. 20, 121-136.

Shimanuki H., Knox D.A. (2000) Diagnosis of honey bee diseases, U.S. Dept. Agric., Ag. Handbook No. 690.

Tautz J., Maier S., Groh C., Rossler W., Brockmann A. (2003) Behavioral performance in adult honey bees is influenced by the temperature experienced during their pupal development, Proc. Natl Acad. Sci. (USA) 100, 7343-7347. 